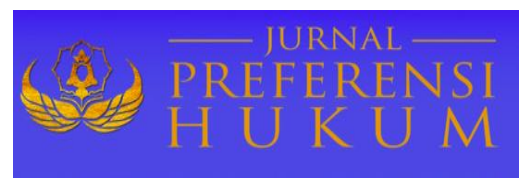

Jurnal Preferensi Hukum | ISSN: XXXX | E-ISSN: XXXX

Vol. 1 No. 1 - Juli 2020 hal. 52-58| Available online at

https://www.ejournal.warmadewa.ac.id/index.php/juprehum

\title{
PROSES PERMOHONAN HAK PAKAI ATAS TANAH MILIK PRIBADI OLEH WARGA NEGARA ASING
}

\author{
I Komang Andi Darmawan, A.A Sagung Laksmi Dewi, I PT GD Seputra \\ Fakultas Hukum Universitas Warmadewa, Denpasar - Bali, Indonesia
}

\begin{abstract}
Abstrak
Penelitian ini bertujuan untuk mengetahui proses permohonan hak pakai atas tanah milik pribadi oleh warga negara asing di Indonesia, dimana sesuai dengan peraturan yang berlaku di Indonesia yang sudah ditetapkan oleh undangundang No. 5 Tahun 1960 tentang peraturan dasar-dasar pokok agraria, dan juga Peraturan Pemerintah No. 40 Tahun 1996 tentang Hak Guna Bangunan, Hak Pakai, dan Hak Guna Usaha, serta pendaftaran atas tanah yang diatur dalam Peraturan Pemerintah No. 24 Tahun 1997. Penelitian ini didasarkan pada penelitian hukum normatif yang bersifat teknis atau terapan. Pendekatan penelitian ini juga menggunakan pendekatan Undang-undang dan pendekatan kasus yang sudah/sedang terjadi. Jenis data penelitian ini adalah dengan bahan hukum primer dan bahan hukum sekunder. Teknik pengumpulan data ini dilakukan dengan studi kepustakaan dan teknik analisis data yang digunakan bersifat deduksi dengan metode silogisme. Hasil penelitian ini menunjukan bahwa warga negara asing yang berada di Indonesia dapat memiliki hak pakai atas tanah yang ada di Indonesia berupa Hak Guna Bangunan, Hak Pakai, dan Hak Guna Usaha, dimana warga negara asing di berikan batas-batas waktu dalam memiliki atau memakai atas tanah yang berada di Indonesia, agar tidak ada terjadinya warga negara asing yang dapat memiliki atau membeli tanah di Indonesia atas nama orang asing tersebut yang kita tau bahwa tanah di Indonesia hanya di peruntukan untuk warga Indonesia.
\end{abstract}

Kata Kunci: Hak Pakai; Tanah Milik Pribadi; Warga Negara Asing

\begin{abstract}
This study aims to determine the process of application for usage rights on private land by foreign citizan in Indonesia which is in accordance with the Regulations in force in Indonesia that have been established by law No. 5 of 1960 concerning the rules of the basic principles of agrarian, and also Government Regulation No. 40 of 1996 concerning right to build, right to use, and right to use, as well as registration of land which is regulated in Government Regulation No. 24 of 1997. This research is based on normative legal research that is technical or applied. This research approach also uses a law approach and a case approach that has/is happening. Types of data in this study are primary and secondary legal materials. This data collection technique is carried out in the form of literature study and data analysis techniques used are deduction with the syllogism method. The results of this study indicate that foreign nationals residing in Indonesia can have rights to use land in Indonesia in the form of building use rights, use rights and business use rights, in which foreign citizens are given time limits in owning or using on land in Indonesia, so that there is no occurrence of foreign nationals who can own or buy land in Indonesia on behalf of these foreigners, we know that land in Indonesia is only intended for Indonesian citizens.
\end{abstract}

Keywords: Rights of Use; Private Land; Foreign Citizen

\section{PENDAHULUAN}

Di Indonesia kita mengetahui bahwa WNA yang dapat mempunyai hak dalam memakai tanah yang sudah ada dalam Pasal 1 ayat 1PP 41 Tahun 1996 dimana diperbolehkannya WNA yang keberadaanya di dalam wilayah Indonesia dapat mempunyai hunian. Didalam Pasal 1 ayat 2 PP 41 Tahun 1996 yang memuat syarat WNA dapat diperbolehkan memiliki hunian yang berada di Indonesia adalah WNA yang keberadaannya 
memberikan pertumbuhan ekonomi di Indonesia. Berikutnya Pasal 2PP 41 Tahun 1996 dalam pasal ini menyebutkan pembatasan WNA tersebut yang dibatasi hanya dapat mempunyai tidak lebih dari satu hunian di Indonesia yang bisa berupa rumah atau rumah susun yang telah diberikan (Harsono, 2003:03). Pasal 5 ayat 1 Peraturan Pemerintah 41 Tahun 1996 dimana dibatasinya WNA dalam menyewa tanah di dalam wilayah Indonesia hanya dalam waktu kurang dari 25 tahun. Ada juga jenis-jenis lainnya yang dalam jangka waktu seperti hak pakai, hak guna usaha, hak guna bangunan, (dimana ini untuk warga negara Indonesia) yang dibolehkan menambah durasi waktu menyewa tanah dalam batas waktu yang sudah ditetapkan setelah pemberian waktu pertama telah berakhir. Untuk pemberian hunian kepada WNA tidak bisa di perpanjang, tapi bisa diperbaharui dalam maksimal waktu 25 tahun, dengan batasan-batasan WNA ini masih berada di dalam wilayah Indonesia dan ini sudah diatur dalam Pasal 5 ayat 2 PP 41 Tahun 1996.

Peratuan Pemerintah 41 Tahun 1996 yang membatasi hunian yang bisa di miliki WNA dalam hal ini terdiri dari tanah negara dan tanah milik pribadi. Dalam kepemilikan kepada WNA harus berdasarkan kepada perjanjian yang sudah disepakati dari para pihak yang melakukan yang dimana telah di buat oleh seorang pejabat notaris (PPAT). Didasarkan dalam Peraturan Pemerintah ini tidak adanya di tuliskan hunian dapat dipunyai WNA dalam hak pakai yang berasal dalam hak pengelolaan. Kepemilikan WNA dalam memiliki hak dalam memakai tanah mempunyai jangka waktu tertentu apalabila jangka waktu ini telah berakhir masa berlakunya, diharuskannya WNA tersebut harus memperpanjang masa berlakunya. Di terbitkannya undang-undang No. 25 Tahun 2007 dalam berinvestasi di Indonesia merupakan perubahan dari undang-undang No. 11 Tahun 1970 dalam perubahan undang-undang No. 1 Tahun 1967 tentang investasi warga negara asing (yang berikutnya di sebut UUPMA) yang membukanya peluang bagi investor luar negeri mempunyai tanah dalam investasi di Indonesia, dimana dapat mempermudah warga negara asing dalam melakukan investasi di Indonesia.

Dengan adanya Undang-undang PMA diharapkan dimudahkannya WNA dalam berinvestasi di dalam wilayah Indonesia semakin bertambah. Dalam hal ini baik dalam pembangunan di dalam negeri undang-undang ini juga dapat memuat kepastian hukum yang dimana baik dalam perkembangan ekonomi di dalam wilayah Indonesia. Ini juga dapat menaikkan perkembangan ekonomi dalam negeri, meningkatkan lapangan-lapangan kerja baru, menaikkan mutu didalam dunia wirausaha di Indonesia, menaikkan kemakmuran penduduk Indonesia, dapat juga menaikkan perkembangan IPTEK Indonesia.

Para WNA yang berinvestasi di dalam wilayah Indonesia, bisa berupa industri, yang mana diperlukan ketersediaanya berupa tanah untuk keperluan industri ini. Para WNA ini juga membutuhkan prasarana dalam bentuk gedung perkantoran atau hunian tempat tinggal. Namun, para WNA ini tidak bisa mengelola hak dalam tanahnya secara mandiri ataupun secara badan hukum yang didirikan di dalam wilayah Indonesia dikarenakan pengaturan pemerintah yang tidak memperbolehkan WNA memiliki tanah di Indonesia. Yang diperbolehkan adalah WNA berhak mendapatkan hak atas tanah berupa hak pakai yang diatur dalam pasal 42 UUPA dan hak sewa yang diatur dalam pasal 45 UUPA, (Tambing \& Kartika, 2016). Pengaturan kepemilikan hak atas tanah bagi Warga Negara Asing di Indonesia aturan yang mengatur sudah sangat jelas. Mulai dari Undang-Undang Dasar Negara Republik Indonesia, dalam Pasal 33 ayat (3), kemudian Undang-Undang Nomor 5 Tahun 1960 tentang Undang-Undang Pokok Agraria (Ardani, 2017). Ini didukung oleh hasil penelitian dari Putra, Darmadi, \& Indrawati (2013) bahwa kebijakan pemberian hak atas tanah kepada WNA telah diatur dalam UU Nomor 5 tahun 1960 yaitu Hak Pakai dan Hak Sewa Atas Tanah. Rokilah \& Mukaromah (2018) menyatakan bahwa hak atas tanah bersifat sementara ditetapkan dalam Pasal 53 ayat (1) UUPA yaitu, Hak Gadai, Hak Usaha Bagi Hasil, Hak Menumpang, Hak Sewa Tanah Pertanahan. Untuk warga negara asing tidak terbuka kemungkinan untuk mendapatkan hak atas tanah dalam hukum sistem hukum pertanahan, kecuali hak pakai.

Para WNA juga bisa mempunyai kesempatan dalam mengelola tanah-tanah lain yang berada di Indonesia mengenai Hak Pakai dalam Peraturan Pemerintah 41 Tahun 1996 adalah dasar yang dapat di miliki bagi WNA di dalam wilayah Indonesia berupa hunian (rumah). Pengaturan mengenai pemilikan rumah tempat tinggal bagi orang asing yang berkedudukan di Indonesia oleh pemerintah hanya diberikan status Hak Pakai, dan bukan Hak Milik (Sutrisna \& Gunarto, 2017). Peraturan Pemerintah 41 Tahun 1996 memberikan kepastian hukum dalam mempunyai hunian untuk WNA tinggal di dalam wilayah Indonesia. Ini juga sudah tegas ditemukan didalam Pasal 1 ayat 1 dan ayat 2. Namun, WNA masih belum memahami 
proses permohonan hak pakai atas tanah milik pribadi dikarenakan tingkat pemahaman yang rendah dari masyarakat yang tinggal di atas tanah Negara, (Pramuditya, Raharjo, \& Mulyoto, 2016).

Beberapa penelitian terkait dengan penelitian sekarang ini telah dikaji sebelumnya, diantaranya Sumanto (2013) yang mengkaji tentang "Pembatasan Pemilikan Hak Atas Tanah oleh Orang Asing dan Badan Hukum Asing (Studi Perbandingan Indonesia - Turki)". Hasil penelitian ini menunjukkan bahwa orang asing dan badan hukum asing di Indonesia dibatasi hanya dapat memiliki tanah berstatus Hak Pakai dengan syarat orang asing berkedudukan di Indonesia dan kehadirannya memberi manfaat bagi pembangunan Nasional, sedangkan badan hukum asing mempunyai perwakilan di Indonesia". Sudana \& Sastrawan (2017) mengkaji tentang "Proses Pembatalan Sertifikat Hak Milik Atas Tanah dan Perlindungan Hukumnya Berdasarkan Putusan Pengadilan di Pengadilan Negeri Singaraja". Hasil penelitian menunjukkan bahwa Proses pembatalan sertifikat hak milik atas tanah melalui putusan pengadilan secara garis besar melalui dua tahap. Tahap pertama adalah tahap pemeriksaan di depan sidang pengadilan. Setelah ada putusan pengadilan yang memiliki kekuatan hukum tetap dilanjutkan dengan tahap kedua, yaitu tahap pembatalan hak atas tanah, termasuk sertifikat sebagai bukti formil atas hak tersebut oleh Badan Pertanahan Nasional, berdasarkan permohonan yang diajukan oleh pihak yang berkepentingan. Selanjutnya, Nurlaila, Ismail, \& Syahbandir (2018) meneliti "Kepemilikan Tanah Hak Milik yang Dikuasai Bersama Warga Negara Indonesia (WNI) dan Warga Negara Asing (WNA) yang Diperoleh Berdasarkan Warisan di Provinsi Aceh". Berdasarkan analisis, hasil penelitian ini menunjukkan bahwa peralihan hak milik atas tanah yang dikuasai bersama Warga Negara Indonesia (WNI) dan warga negara asing (WNA) yang diperoleh berdasarkan warisan dilakukan melalui akta jual beli kemudian disertifikasi oleh Badan Pertanahan Nasional, dimana ditanda tangani oleh pemilik WNI dan WNA yang seharusnya tidak ada lagi pencantuman WNA di sana, namun karena beralaskan ahli waris mereka tetap memperolah hak yang secara hukum tertulis sebenarnya mereka telah kehilangan haknya. Berdasarkan latar belakang dan penelitian terdahulu di atas, penelitian ini bertujuan untuk mengetahui proses permohonan hak pakai atas tanah milik pribadi oleh warga Negara asing di Indonesia.

\section{METODE}

Penelitian ini menggunakan jenis penelitian normatif. Penelitian normatif yaitu penelitian hukum yang dilakukan dengan cara meneliti bahasa pustaka atau data sekunder sebagai bahan dasar untuk diteliti dengan cara mengadakan penelusuran terhadap peraturan-peraturan dan literature-literatur yang berkaitan dengan permasalahan, (Soekanto \& Mamudji, 2001). Pendekatan masalah yang digunakan adalah pendekatan dalam undang-undang dan pendekatan konseptual. Pendekatan masalah dilakukan dengan kajian terhadap peraturan perundang-undangan yang berlaku yang memiliki keterkaitan dalam masalah yang akan ditulis dan pendekatan konseptual dengan cara menganalisis permasalahan melalui konsep hukum yang diambil dari literatur dan buku-buku yang memiliki keterkaitannya dengan permasalahan yang dibahas. Sumber bahan hukum dari penelitian ini adalah bahan hukum primer meliputi bahan hukum yang memiliki sifat autoriatif atau yang memiliki kepastian hukum mengikat, yaitu adalah undang-undang No. 5 Tahun 1960 Tentang Peraturan Dasar Pokok Agraria, Peraturan Pemerintah No. 46 Tahun 1996 Tentang Hak pakai, Hak guna bangunan, Hak guna usaha. Bahan hukum sekunder yang di pakai yaitu bahan hukum yang memberikan keteranganterhadap bahan hukum primer, yang meliputi literatur, makalah, buku-buku, dan bahan-bahan hukum tertulis lainnya yang berhubungan dalam permasalahan penelitian ini.

\section{HASIL DAN PEMBAHASAN}

\section{Proses Permohonan Warga Negara Asing dalam Hak Pakai atas Tanah di Indonesia}

Warga Negara Asing yang keberadaanya di Indonesia dapat dibedakan menjadi dua jenis:

1. Warga Negara asing yang berada di dalam wilayah Indonesia secara tetap (warga negara asing yang ingin memiliki izin tinggal tetap).

2. Warga Negara Asing yang tidak tetap berada didalam wilayah Indonesia hanya dalam waktu sementara tinggal di Indonesia (dimana memiliki izin kunjungan/izin imigrasi lainnyayang dalam bentuk paspor, visa ataupun,dokumen-dokumen lainnya. 
Berkaitannya Hak atas tanah bagi para bagi investor dari luar negeriyang ada di Indonesia, undangundang pokok agraria disebutkan bahwa WNA yang bisa mempunyai hak pakai dan hak sewa sebagai hunian adalah WNA yang telah berada di Indonesia. Walaupun begitu undang-undang pokok agraria tidak dijelaskannya secara rinci yang mau dimaksudkan dengan kedudukan WNA yang berada di dalam wilayah Indonesia. Bila di sambungkan pada Peraturan Pemerintah No. 40 Tahun 1996 didalam Pasal 1 ayat 2 disebutkannya WNA bertempat di Indonesia adalah orang-orang dari luar negeri keberadaanya di Indonesia dapat membuat perkembangan ekonomi nasional di Indonesia semakin meningkat (Santoso, 2015:21).

Berikutnya, dalam Pasal 1 ayat 1 Peraturan Pemerintah 103 Tahun 2015 sangat rinci disebutkan orang berkebangsaan asing tinggal di Indonesia merupakan tidak penduduk asli Indonesia yang dimana keberadaan WNA ini dapat meningkatkan baik secara pembangunan, membukanya lapangan kerja baru, maupun berinvestasi di Indonesia. Apa yang sudah diuraikan tulisan diatas, bahwa kita dapat simpulkan WNA yang ingin mempunyai kepemilikan atas tanah di Indonesia baik hak pakai ataupun hak sewa sebagai pembangunan harusnya WNA yang dimana telah tinggal dan telah membuka usaha yang dimana bisa di buktikan dalam mempunyai kartu izin tinggal terbatas atau kartu izin tinggal tetap.

WNA yang memiliki izin menetap di dalam wilayah Indonesiaadalah izin yang hanya dapat diberikan pejabat keimigrasian, atau pejabat dinas luar negeri kepada warga negara asing yang bertempat tinggal diIndonesia.

Disebutkan dalam Pasal 141 PP No. 31 Tahun 2013 yang dirubah menjadi PP No. 26 Tahun 2016 disebutkan bahwa peraturan pelaksanaan undang-undang No. 6 Tahun 2011 dimana Peraturan Pemerintah imigrasi telah disebutkan: izin tinggal terbatas diberikan hanya kepada:

- Warga negara asing memasuki Indonesia dengan visa tinggal terbatas.

- Anak-anak yang akan lahir di dalam wilayah Indonesia ayah maupun ibunya pemegang izin tinggal terbatas.

- Warga negara asing telah diberikannya status dari izin tinggal kunjungan.

- Tenaga ahli, awak kapal, atau nahkoda warga negara asing didalam instalasi, alat apung, maupun di atas kapal laut, yang dimana beroprasinya didalam wilayah yurisdiksi dan perairan Indonesia sesuai dengan kentetuan undang- undang yang berlaku.

- Warga negara asing telah menikah secara sah dengan pasangan warga asli Indonesia.

- Anak-anak warga negara asing telah menikahi anak dari warga negara asing yang menikah secara sah dengan warga negara Indonesia.

Bila ingin memiliki izin tinggal terbatas sudah seharusnya warga negara asing tersebut bisa memberikan pengajuan permohonan izin tinggal terbatas kepada pejabat imgirasi yang telah ada di wilayah kerja orang asing tersebut. Izin-izin tinggal terbatas yang telah di berikan oleh pejabat imigrasi dalam waktu yang biasa paling lama dalam waktu dua tahun dan akan di perpanjang jika tenggang waktunya telah habis. Bila ingin tiap kali menambah masa berlaku tersebut telah di berikan biasanya akan memakan waktu paling lama dua tahun dan adanya berbagai ketentuan keseluruhan memiliki waktu tinggal di Indonesia yang bila dihitungkan dalam waktu enam tahun sebagaimana telah ada aturan yang jelas dalam Pasal 148 Peraturan Pemerintah keimigrasian.

Izin ingin tinggal menetap tinggal di Indonesia adalah izin yang dimana akan di berikan kepada warga negara asing tertentu saja yang dapat tinggal tetap di dalam wilayah Indonesia ingin sebagai warga Indonesia. Telah jelas pada Pasal 152 Peraturan Pemerintah keimigrasian yang telah menyebutkan bahwa ingin memiliki perizinan menetap hanya orang-orag yang memiiki hak telah memiliki izin tinggal terbatas sebagai, pekerja, investor,lanjut usia, dan rohaniawan, keluarga karena perkawinan campuran, suami, istri, dan anak dari warga negara asing pemegang izin tinggal tetap, dan warga negara asing kewarganegaraan Indonesia dan ek subjek anak kewarganegaraan ganda republik Indonesia.

Dalam memohon izin tinggal menetap dapat diberikan kepada WNA yang berkepentingan kepada kepala kantor imigrasi telah ada dimana warga asing tersebut bertempat tinggal. Telah sesuai dalam pasal 155 PP keimigrasian, izin tinggal tetap yang sudah didapat dalam jangka lima Tahun. Terutama kepada izin 
tinggal tetap dapat memperpanjang masa berlakunya dalam batas waktu tidak terbatas dengan ketentuan izin tinggalnnya tidak dibatalkan.

Dalam pasal 167 PP keimigrasian, izin tinggal terbatas bisa dialihkan status menjadi izin tinggal tetap. Pengajuan pemindahan pengalihan status diapat diajukan kepada kepala kantor imigrasi oleh yang menjamin. Terhadap WNA yang bisa mengalih statuskan seperti orang yang telah bekerja, orang yang ingin menanam modal, wisatawan yang telah tua, maupun rohaniawan, suami- istri yang menikah dengan suami atau istri yang memiliki izin tinggal tetap, anak yang usianya belum dewasa dimana di Indonesia dibataskan pada umur 18 tahun dan tidak menikah dan dapat menggabungkan dengan orang tua yang memiliki izin tinggal tetap dan WNA eks warga negara Indonesia. Pengalihan status bisa di berikan dengan catatan bahwa WNA ini lama tinggal dan berada di dalam wilayah Indonesia dalam kurun waktu 3 tahun berturut-turut sejak tanggal dimana dikeluarkannya izin tinggal terbatas tersebut.

\section{Fungsi dan Peran Notaris/ PPAT Dalam Proses Pemberian Hak Pakai atas Tanah}

Dalam melaksanakan tugasnya seorang PPAT mempunyai kewenangan membuat akta otentik yang terdiri dari 8 (delapan) macam akta, yaitu:

1) akta jual beli.

2) akta tukar menukar.

3) akta hibah.

4) akta pemasukan kedalam perusahaan.

5) akta pembagian hak bersama.

6) akta pemberian hak guna bangunan (HGB)/hak pakai (HP) atas tanah Hak Milik (HM).

7) Pemberian Hak Tanggungan.

8) akta pemberian kuasa membebankan hak tanggungan.

Dari delapan akta di atas maka jual beli termasuk yang paling sering dibuat oleh pejabat PPAT. Berlakunya PP No. 10 Tahun 1961 yang bagaimana adanya pembaharuandengan PPNo. 24 Tahun 1997 dalam pendaftaran tanah, dan jual- beli tanah yang telah di lakukan oleh para pihak yang bersangkutan dihadapan pejabat notaris yang membuat akta tanah atau jual beli tersebut. Akta-akta jual beli telah di sepakati oleh para pihak telah membuktikan terjadinya pemindahan akta dari penjual ke pembeli dengan disertai dengan adanya harga, telah adanya pemenuhan syarat dan adanya penunjukan secara riil/nyata dalam perbuatan jual beli tersebut yang dimana telah dilaksanakan oleh para pihak. Dalam akta perjanjian yang telah di lakukan adalah benar adanya para pihak telah melakukan perbuatan hukum yang dimana para pihak telah melakukan perpindahan hak untuk selama-lamanya dalam pemindahan hak atas akta tersebut telah membuktikan bahwa penerima hak (pembeli) sudah menjadi pemegang hak atas tanah tersebut (Harsono, 2003:77)(Boedi Harsono, 1977:77).

Sering terjadinya jual-beli adalah suatu perjanjian dimana para pihak yang telah melakukan perjanjian tersebut dimana telah terjadinya penyerahan hak milik atas suatu barang dengan pihak yang lain dimana ada harga yang harus dibayar yang telah di perjanjikan sebelum adanya kesepakatan di antara kedua belah pihak (Subekti, 1986:79). Karena itu jual-beli yang dimana merupakan sebuah pernjanjian, maka berlakunya syarat-syarat sahnya perjanjian. Yang mana telah di atur dalam pasal 1320 KUHPerdata, untuk syarat sahnya suatu perjanjian yang di buat: :

a) Terjadinya kesepakatan yang mengikat.

b) Terjadinya kecakapan untuk membuat suatu perjanjian.

c) Adanya suatu hal tertentu.

d) Adanya suatu sebab yang halal.

Didalam KUHPerdata tidak di berikannya kejelasan apa yang dimaksud dengan sebab yang halal, akan tetapi dalam pasal 1337 KUHPerdata adanya aturan dalam sebab terlarang, yang dimana dimaksudkan sebab yang bertolak belakang dengan undang-undang, ketertiban umum, dan kesusilaan. Bila menafsirkan pasal 1337,kita dapat mengetahui adanya sebab yang halal yang tidak bertentangan dengan ketertiban umum, kesusilaan, dan undang-undang (Harahap, 1986: 220). Dalam PP No. 24 Tahun 1997 tentang pendaftaran tanah, pemindahan tanah dan lainnya dimana telah terjadi dengan akta notaris. Penyerahan 
harus memenuhi formalitas undang-undang, meliputi pemenuhan syarat yang dilakukan. Biasanya akan muncul kesulitan-kesulitan dari pihak pertama atau ahli waris yang menolak atau telah pindah tempat tinggal ke daerah lain maka mengulangan perbuatan hukum peralihannya tidak dapat dilakukan.

Terbentuknya surat perjanjian dalam notaris sebagai akta ontetik sangatlah menentukan, apabila pihak yang bersangkutan terbukti dapat membuktikan terjadinya cacat hukum didalam isinya atau adanya kesalahan atau ketidakpastian dalam pembuatannya maka akan timbulnya masalah-masalah hukum yang tercatat dalam akta tersebut (Mertokusumo, 2004:70-71).

\section{SIMPULAN}

Proses kepemilikan hak pakai atas tanah bagi Warga Negara Asing di Indonesia telah sangat jelas diatur. Dimulai dengan UUPA, Pasal 33 ayat 3, dan juga adanya undang-undang No. 5 Tahun 1960 tentang UUPA, dalam pelaksanaannya, dengan keberadaan WNA yang dapat memiliki hunian didalam wilayah Indonesia. Negara hanya memberikan status hak pakai, dan bukan hak milik. Meskipun begitu negara tetap memberikan fasilitas kemudahan bagi WNA yang ingin berinvestasi di Indonesia dengan di keluarkannya kebijakan-kebijakan yang salah satu pelaksanaannya di atur berdasarkan Peraturan Pemerintah Nomor 40 Tahun 1996 tentang WNA hanya bisa menggunakan hak guna bangunan dan hak guna usaha oleh warga negara asing yang berkedudukan di Indonesia.

Berdasarkan aturan hukum yang berlaku fungsi pejabat PPAT/Notaris dalam pemberian hak pakai kepada warga negara asing yang bertempat tinggal di dalam wilayah Indonesia adalah dapat menjamin dan memberikan kekuatan hukum dalam pemberian hak sewa dan hak pakai pakai atas tanah warga negara asing yang ingin tinggal di Indonesia dan juga pemberian jangka waktu yang sesuai dengan Peraturan Pemerintah No. 103 Tahun 2015 dimana disebutkan hak warga negara asing dalam mempunyai tanah di dalam wilayah Indonesia diberikan batasan waktu dalam kurun waktu 30 tahun, agar tidak ada terjadinya warga negara asing bisa mempunyai kepemilikan tanah di dalam wilayah Indonesia atau melebihi aturan tinggal lebih dari 30 tahun.

Sehubungan dengan warga negara asing telah berada di wilayah Indonesia menggunakan kepemilikan atas tanah di Indonesia yang bentuknya adalah hak guna usaha atau hak guna bangunan, maka negara hendaknya memberikan fasilitas kebijakan-kebijakan yang dapat mengurangi resiko warga negara asing yang dapat melanggar peraturan hukum di Indonesia. Pemerintah dapat mengawasi/mengontrol pemberian hak pakai atas tanah warga negara asing yang selama 30 Tahun, agar tidak ada terjadinya WNA melebihi waktu hak pakai yang sudah di tentukan tersebut. Masyarakat juga dapat memiliki wawasan dalam pemberian hak pakai atas tanah oleh WNA yang berlaku di Indonesia, agar kedepannya tidak ada lagi sengketa WNA yang ingin menyewa tanah yang ada di Indonesia.

\section{DAFTAR PUSTAKA}

Ardani, M. N. (2017). Kepemilikan Hak Atas Tanah Bagi Orang Asing di Indonesia. LAW REFORM, 13(2), 204. doi:10.14710/lr.v13i2.16156

Harahap, M. Y. (1986). Segi- Segi Hukum Perjanjian. Bandung: Alumni.

Harsono, B. (2003). Menuju Penyempurnaan Hukum Tanah Nasional Dalam Hubungannya Dengan TAP MPR RI IX/MPR/2001 (Cet 2). Jakarta: Universitas Trisakti.

Mertokusumo, S. (2004). Penemuan Hukum: Sebuah Pengantar. Yogyakarta: Liberty.

Nurlaila, N., Ismail, I., \& Syahbandir, M. (2018). Kepemilikan Tanah Hak Milik Yang Dikuasai Bersama Warga Negara Indonesia (WNI) dan Warga Negara Asing (WNA) yang Diperoleh Berdasarkan Warisan di Provinsi Aceh. Syiah Kuala Law Journal, 2(2), 258-275. doi:10.24815/sklj.v2i2.11633

Pramuditya, P. E., Raharjo, P. S., \& Mulyoto. (2016). Pelaksanaan Pendaftaran Hak Milik Atas Tanah Negara di Surakarta (Studi di Kantor Pertanahan Kota Surakarta). Repertorium, 3(2), 106-113. Retrieved from http://jurnal.unsyiah.ac.id/SKLJ/article/view/11633

Putra, I. P. I. M., Darmadi, A. A. S. W., \& Indrawati, A. A. S. (2013). Kepemilikan Hak Pakai atas Tanah bagi Warga Negara Asing di Kabupaten Badung Provinsi Bali. Kertha Semaya: Journal Ilmu Hukum, 1(2), 1-5. Retrieved from http://e-jurnal.lppmunsera.org/index.php/ajudikasi/article/view/972

Rokilah, R., \& Mukaromah, M. (2018). Pemilikan Hak Atas Tanah Bagi Warga Negara Asing. Ajudikasi : Jurnal Ilmu Hukum, 2(2), 137. doi:10.30656/ajudikasi.v2i2.972 
Santoso, U. (2015). Perolehan Hak Atas Tanah. Jakarta: Prenada Media Group.

Soekanto, S., \& Mamudji, S. (2001). Penelitian Hukum Normatif (Suatu Tinjauan Singkat). Jakarta: Rajawali Pers.

Subekti, R. (1986). Hukum Perjanjian (Cet. 10). Jakarta: PT Intermasa.

Sudana, M. A. P., \& Sastrawan, K. W. (2017). Proses Pembatalan Sertifikat Hak Milik Atas Tanah dan Perlindungan Hukumnya Berdasarkan Putusan Pengadilan di Pengadilan Negeri Singaraja. Kertha Widya: Jurnal Fakultas Hukum UNIPAS, 5(2), 1-21. doi:https://doi.org/10.37637/kw.v5i2.284

Sumanto, L. (2013). Pembatasan Pemilikan Hak Atas Tanah oleh Orang Asing dan Badan Hukum Asing (Studi Perbandingan Indonesia - Turki). Jurnal Hukum PRIORIS, 3(3), 67-102. Retrieved from https://trijurnal.lemlit.trisakti.ac.id/prioris/article/view/369

Sutrisna, D. A., \& Gunarto. (2017). Tinjauan Yuridis Tentang Pemilikan Rumah Orang Asing yang Berkedudukan di Indonesia. Jurnal Akta, 4(2), 241. doi:http://dx.doi.org/10.30659/akta.4.2.239\%20$\% 20250$

Tambing, V. N., \& Kartika, I. G. A. P. (2016). Indonesia Dan Akibat Hukum Terhadap Hak Milik. Kertha Semaya: Journal Ilmu Hukum, 4(3), 1-6. Retrieved from https://ojs.unud.ac.id/index.php/kerthasemaya/article/view/18964 